\title{
USE OF THE FINITE ELEMENT METHOD IN PREDICTING VIBRATIONS OF SANDWICH BEAMS AND PLATES RESTING ON DEFORMABLE FOUNDATIONS SUBJECTED TO MOVING LOADS
}

\author{
A. ZBICIAK ${ }^{1}$, M. ATAMAN ${ }^{2}$, W. SZCZEŚNIAK ${ }^{3}$
}

\begin{abstract}
This paper presents the capabilities of ABAQUS finite-element program [1] in modelling sandwich beams and plates resting on deformable foundations. Specific systems of sandwich beams and plates separated by an elastic core layer were subjected to the action of point and distributed moving loads. A few theoretical examples are provided to present different techniques of modelling the foundations and the moving loads. The effects of the boundary conditions and of the foundation parameters on the deflections of the analysed structures are also presented.
\end{abstract}

Keywords: vibrations of composite beams and plates, deformable foundations, point and uniformly distributed moving loads, finite-element method

\section{INTRODUCTION}

Dynamic analysis of beams and plates subjected to the action of moving loads is a crucial element of the design of bridge structures, road and airport pavements and railway superstructures. The travel speeds and accelerations of vehicles are among the main factors influencing the deflections, displacements and stresses induced in these structures. The traffic surfaces are most often designed

\footnotetext{
${ }^{1}$ DSc., PhD., Eng., Warsaw University of Technology, Faculty of Civil Engineering, Al. Armii Ludowej 16, 00-637 Warsaw, Poland, e-mail: a.zbiciak@il.pw.edu.pl

${ }^{2} \mathrm{PhD}$., Eng., Warsaw University of Technology, Faculty of Civil Engineering, Al. Armii Ludowej 16, 00-637 Warsaw, Poland, e-mail: m.ataman@il.pw.edu.pl

${ }^{3}$ Prof., DSc., PhD., Eng., Lublin University of Technology, Faculty of Civil Engineering and Architecture, ul. Nadbystrzycka 40,20-618 Lublin, Poland, e-mail: w.szczesniak@il.pw.edu.pl
} 
with the use of empirical design methods and typical designs provided by them or by solving statics problems and adjusting the results by application of a dynamic amplification factor.

Vibrations of beams and plates excited by moving loads have been analysed for quite a long time by researchers from many different research centres. The problem of vibrations of a flexible simple beam excited by a moving point force (i.e. load without inertial effect) was analysed by Krylov way back in the year 1905 [34]. The analysis was extended by calculating a closed form of the particular integral in the string problem and subsequently in a simple beam problem and presented by Krylov in the monographs [36] and [35] published in 1913. A number of researchers discussed in their papers the closed form of the particular integral in the Krylov problem, including Rutshimsky [53], Kączkowski [29], Śniady [68], Szcześniak and Ataman [61].

Loading of beams and plates by a moving mass (i.e. load having inertial effect) was the subject of the first papers published by Stokes [54] and papers of other authors [16], [77], [36], [46] which were devoted to analysing a massless beam loaded by a moving point mass. Further studies on loading beams with a moving mass were conducted by Renaudot [52], Bolotin [11-13] and also by Morgaevskij et al., reported [43]. The problem was also studied by Michaltsos and Kounadis [42] and many other researchers from different countries including the following Polish researchers: Naleszkiewicz [47], Kączkowski [28-29], Langer [37-38], Langer, Klasztorny [40], Śniady [65-66], Klasztorny [32], Szcześniak [57], [59].

Vibrations of beams and plates excited by moving oscillators were analysed for example in [62-64]. The effect of the number of terms in a series on the solution of a problem in which a visco-elastic one-mass oscillator is moving on a beam was investigated by Bajer [10] and also by Szcześniak, Ataman and Zbiciak [60].

Among many review articles concerning the action of moving loads on beams and plates the most prominent are the papers of Jakushev [23-26], Szcześniak [57-59], Ting et al. [69], Panovko [50] and Kerr [30]. The most important monographs and manuals on the subject were written by Frýba [18-19], Mutshnikov [45], Kolesnik [33], Bondar et al. [14], Inglis [22], Filippov and Kohmaniuk [17], Langer [39], Śniady [67], Klasztorny [31] and also Bartshenkov [10]. Also worth noting is the monograph by Yang, Yau and $\mathrm{Wu}$ [72].

Vibrations of sandwich structures (such as two beams or plates bonded by an elastic layer) excited by moving loads were also investigated. This subject was studied by Oniszczuk [48], Szcześniak [55-56], Ataman [4], Ataman and Szcześniak [5] and many others while beams of transversely nonuniform stiffness subjected to the action of a moving load are studied in [6] and [7]. 
The main limitation in the application of analytical methods for finding solutions of dynamic problems of beams/ plates subjected to the action of moving loads is related to fulfilling the boundary conditions in them. Hence, in most cases approximation methods are used, including the finite element method (FEM), space-time finite element method, boundary element method, differential quadrature method (DQM) and finite difference method (FDM) which enable easy modelling of any boundary conditions. Moreover, these methods allow considering different properties of the analysed materials and structural components.

A number of researchers have used the finite element method to analyse structures subjected to the action of moving loads, including the authors of [70], [41], [3], [74], [44] and examples of application of the Galerkin's method for finite element analysis can be found in [15] and [21]. Examples of application of the space-time finite element method for dynamic structural analysis can be found in [8] and [9]. The boundary element method was used in combination with the finite element method to study the soil-pavement interaction by the authors of [49]. In [27] one can find an example of application of the DQM method for studying vibrations of arch structures.

This paper presents the capabilities of ABAQUS finite-element program [1] for modelling sandwich beams and plates resting on deformable foundations. Systems of sandwich beams and plates separated with an elastic core layer were subjected to the action of point and distributed moving loads. A few theoretical examples are provided in the further part of this paper to present different techniques of modelling the foundations and the moving loads.

It must be made clear that the subroutines described in the paper exceed the conventional application of the ABAQUS suite. As such, the techniques discussed below are not to be found in the ABAQUS user's manuals. Moreover, in many cases we use tools intended for other areas of application. For example, the user subroutine VDLOAD ([2]) is used to model visco-elastic foundation. According to the ABAQUS user's manual [1] algorithms of this subroutine are to be used solely to define loads changing over time. A similar problem will be encountered in defining point or distributed moving force. Also in this case no instructions can be found in the ABAQUS documentation.

ABAQUS, similarly to ANSYS and LS-DYNA has an open architecture permitting inclusion of user-defined subroutines (such as the above-mentioned VDLOAD). This enables users to define their own models of materials, specify boundary conditions and create new finite elements. Moreover, user-defined subroutines can be used to specify non-standard loads and are an effective post-processing tool. The computational capabilities of the systems are expanded with each new version of the suite owing to added new subroutines. FORTRAN language is used to compile a new 
problem and the source code must be included when submitting the problem for analysis. The process of compiling and linking is performed by the system itself as long as the version of the compiler is compatible with the version of the finite-element analysis software.

\section{PINNED-PINNED SANDWICH BEAM RESTING ON A VISCO-ELASTIC FOUNDATION AND LOADED WITH A MOVING POINT FORCE}

This example is given to present how the finite-element method can be used for analysing the dynamic behaviour of a pinned-pinned three-layer beam resting on visco-elastic foundation subjected to the action of a moving load. The following equation describes the vibrations of such beams under the moving force $P$ :

$$
\overline{E J} \frac{\partial^{4} w(x, t)}{\partial x^{4}}+\bar{m} \frac{\partial^{2} w(x, t)}{\partial t^{2}}+\tilde{c} \frac{\partial w(x, t)}{\partial t}+\tilde{k} w(x, t)=P \delta(x-v t)
$$

where:

$w$ - beam deflection, $\overline{E J}$ - equivalent flexural stiffness of a composite beam, $\bar{m}$ - mass of a $1 \mathrm{~m}$ long three-layered beam, $\tilde{c}$ and $\tilde{k}$ - coefficients of Kelvin-Voigt foundation.

For solving the problem with the finite-element method the Kelvin-Voigt foundation VDLOAD user-defined routine was used with the code written in the FORTRAN language. Note that VDLOAD has a corresponding subroutine in the Standard module named DLOAD having a very similar syntax.

Let us first consider a system loaded by a moving force. Such loading is modelled by applying the load through a massless element moving with a specified speed. The most challenging part of building the model is to specify the conditions of contact between the beam and the moving element used to apply the force. For this the routines from the Interaction module ([1]) were used. The following geometrical parameters and material characteristics were applied for the beam: $\rho=2400 \mathrm{~kg} / \mathrm{m}^{3}, \quad l=7 \mathrm{~m}, \quad P=50 \mathrm{kN}, \quad v=20 \mathrm{~m} / \mathrm{s}, \quad \overline{E J}=11,507 \mathrm{MNm}^{2}$. The foundation is described by the following two constants: $\tilde{k}=1,25 \mathrm{MN} / \mathrm{m}^{2}$ and $\tilde{c}=2,0 \mathrm{kNs} / \mathrm{m}^{2}$. The beam has a cross-section of $b \times h=0.25 \times 0.47 \mathrm{~m}$. 
The geometrical model of the beam, including definition of boundary and loading conditions was prepared in ABAQUS/CAE module. The finite-element mesh generated for the purpose of this analysis comprises twenty one nodes and twenty B21 elements (for description of elements see [1]). The system was analysed over a time span of $t \in\langle 0 ; 0.507\rangle \mathrm{sec}$. The step size was calculated by system at $0.000112 \mathrm{sec}$.

The graph in Fig. 1 presents the change over time of vertical displacements of the beam midpoint obtained through solving the problem with finite-element and analytical methods. A very good agreement of the results can be seen despite a relatively small number of finite elements making up the analysed beam.

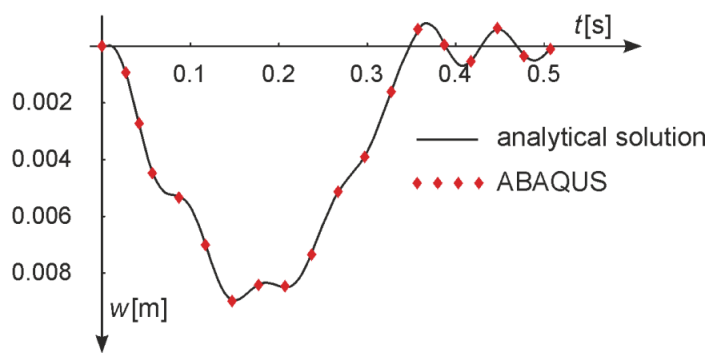

Fig. 1. Comparative analysis of midpoint deflections determined with the finite-element method and analytically with the load moving at a speed of $v=20 \mathrm{~m} / \mathrm{sec}$.

Now let us move to presentation of the load modelling capabilities of the program on the basis of a moving distributed load. Both the foundation and the load were modelled with the same procedure, i.e. VDLOAD. When writing the code it is necessary to bear in mind that the pressures exerted by the foundation and by the moving load should be applied to appropriate parts of the beam. In order to obtain appropriate effect two areas should be defined in the ABAQUS/CAE module whose names should be used in the subroutine code.

The results of three simulations in the form of midpoint vibrations are presented in Fig. 2. It is assumed that the force of $P=50 \mathrm{kN}$ is distributed on the sections of $0.5 \mathrm{~m}, 1.0 \mathrm{~m}$ and $2.0 \mathrm{~m}$ in length, this corresponding to the pressures of $100 \mathrm{kN} / \mathrm{m}, 50 \mathrm{kN} / \mathrm{m}$ and $25 \mathrm{kN} / \mathrm{m}$ respectively. The remaining beam, foundation and the load speed input data are the same as above. Taking account of a different nature of loading a more refined division was applied by adopting 70 -element grid, thus reducing the step size to $4.4 \cdot 10^{-5} \mathrm{sec}$. 


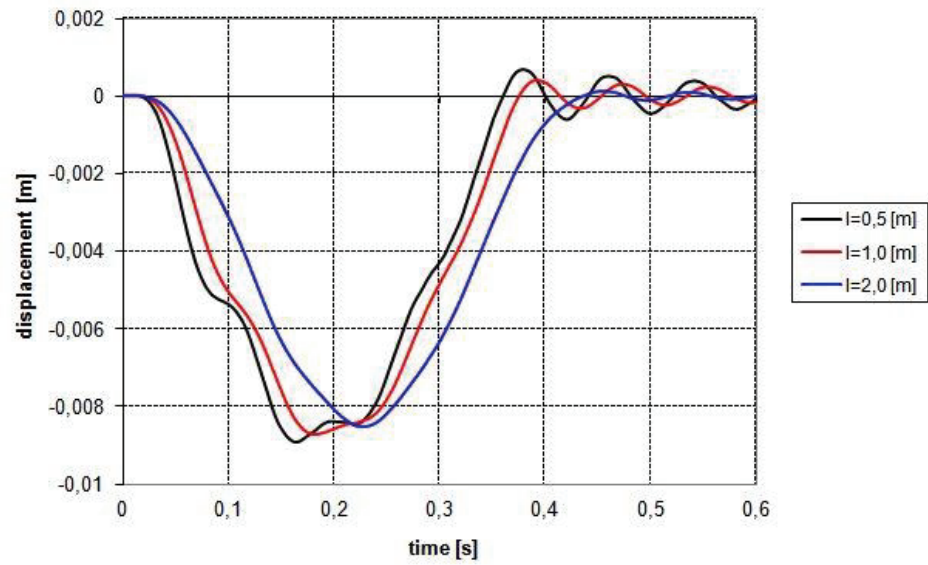

Fig. 2. Midpoint vibration curves for different load distribution lengths

The calculated results clearly show a decrease of the maximum deflection with the increase of the load distribution length. The curves also show "calming" effect of distributed load on the beam vibrations.

\section{SYSTEM OF TWO BEAMS SEPARATED BY AN ELASTIC CORE LOADED BY A MOVING POINT FORCE}

In this section we present a method of modelling elastic action using the spring discrete finite elements available in ABAQUS. The problem under analysis are the vibrations of system of two beams separated by an elastic core resting on a deformable foundation described with the following set of equations:

$$
\begin{gathered}
E_{1} J_{1} \frac{\partial^{4} w_{1}(x, t)}{\partial x^{4}}+\bar{m}_{1} \frac{\partial^{2} w_{1}(x, t)}{\partial t^{2}}+\widetilde{k}_{1}\left[w_{1}(x, t)-w_{2}(x, t)\right]=P \delta(x-v t), \\
E_{2} J_{2} \frac{\partial^{4} w_{2}(x, t)}{\partial x^{4}}+\bar{m}_{2} \frac{\partial^{2} w_{2}(x, t)}{\partial t^{2}}+\widetilde{k}_{1}\left[w_{2}(x, t)-w_{1}(x, t)\right]+\widetilde{k}_{2} w_{2}(x, t)=0,
\end{gathered}
$$

in which all the quantities with subscript "1" concern the top beam and the upper layer of the Winkler's model and the quantities with subscript "2" concern the bottom beam and the lower (elastic) layer of the Winkler's model. 
This technique does not require specifying VDLOAD subroutine in order to allow for the reaction of subgrade. Below are the geometrical parameters and material characteristics of the top and bottom beams, of the elastic core layer and of the foundation. Top beam: $l=6 \mathrm{~m}, \rho=2,500 \mathrm{~kg} / \mathrm{m}^{3}$, $E_{1}=10,300 \mathrm{MPa}, b_{1}=0.2 \mathrm{~m}, h_{1}=0.1 \mathrm{~m}$. Bottom beam: $l=6 \mathrm{~m}, \rho=2,500 \mathrm{~kg} / \mathrm{m}^{3}, E_{1}=30,000$ $\mathrm{MPa}, b_{2}=0.2 \mathrm{~m}, h_{2}=0.3 \mathrm{~m}$. Elastic constants of the core layer and of the foundation: $\tilde{k}_{1}=45,0 \mathrm{MN} / \mathrm{m}^{2}, \tilde{k}_{2}=1,0 \mathrm{MN} / \mathrm{m}^{2}$.

The system is subjected to the action of a moving point force of $P=50 \mathrm{kN}$ moving at a constant speed of $v=30 \mathrm{~m} / \mathrm{sec}$. Let us start by assuming simple support of both beams.

Each beam is made up of 12 finite elements. The springs representing the interaction of elastic core layer and the foundation are connected at the beam nodes and pinned to the foundation. Fig. 3 shows an overview of the system with the deformed beams and elastic elements presented against the contour lines representing the values of equivalent stresses in the outer fibres.

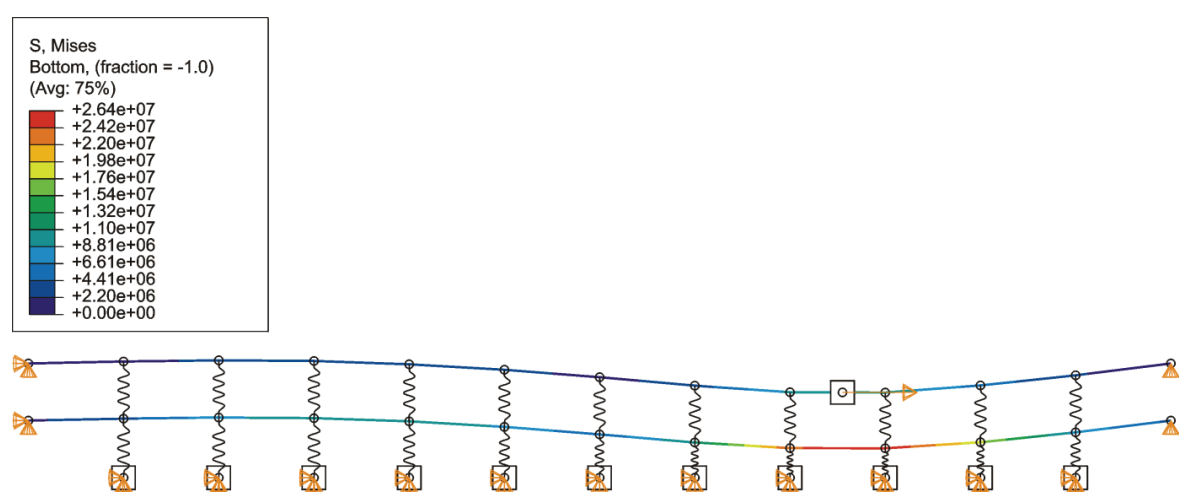

Fig. 3. Overview of the analysed system against the equivalent stress contour lines (outer fibres of beams) at the point in time of $t=0.1425 \mathrm{sec}$. (vertical displacements are exaggerated 6 times)

Fig. 4 presents the midpoint vibration curves for the two beams. The paths of curves are every similar with higher maximum displacements obtained for the top beam which is attributed to the core material deformability. 


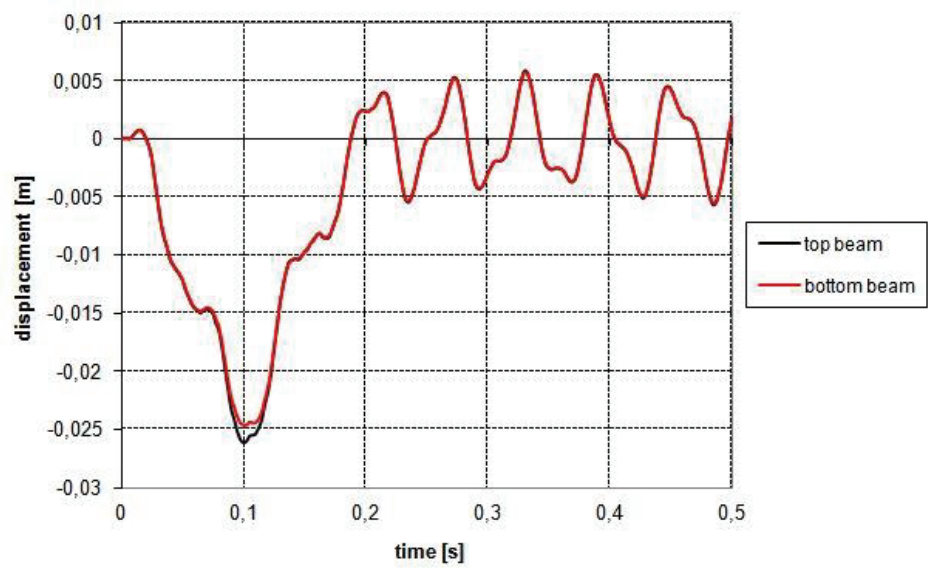

Fig. 4. Change of midpoint displacements over time for the top and bottom beams

With the finite element method approximate solutions can be found which would be much more difficult with analytical methods. In this context we present the results of a comparative analysis of the behaviour of the system composed of two beams with different support conditions. The results of the previous analysis where both beams were simply supported are compared with the results obtained for the system fixed at both ends and the system placed directly on the foundation with no supports in between. In the last case it was necessary to add two pairs of springs at the removed support positions (Fig. 3).

The analytical results in the form of midpoint vibrations of the top beam are presented in Fig. 5. The greatest displacements were obtained for the system with both ends free and the smallest for the systems in which both beams are fixed at both ends. 


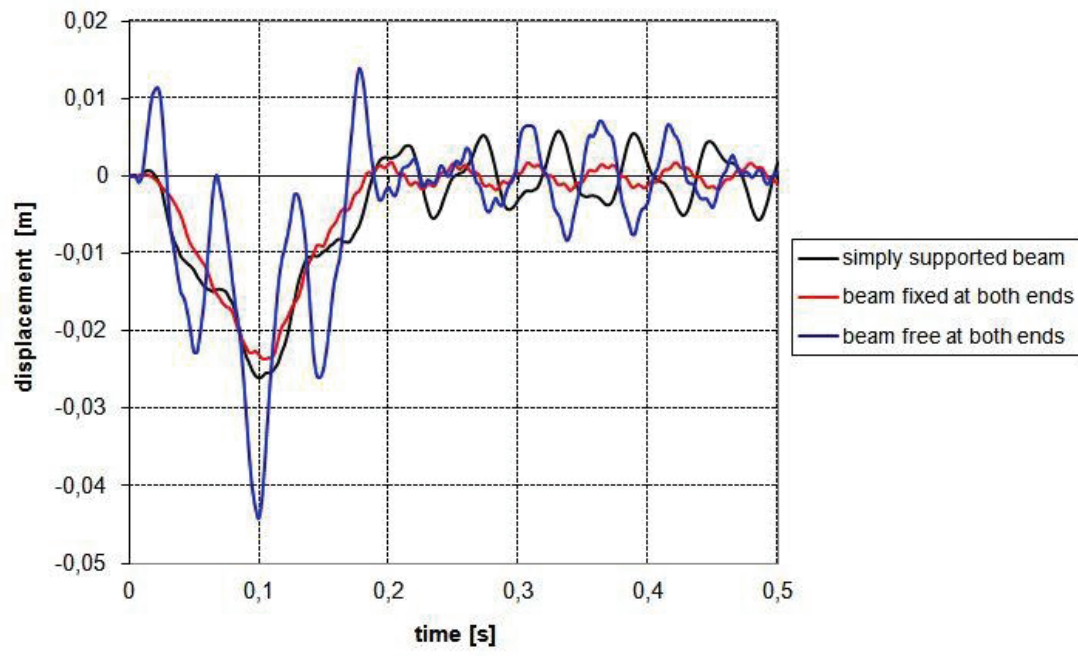

Fig. 5. Influence of boundary conditions on the curve describing midpoint vertical displacements of the top beam for different end support conditions

\section{SYSTEM OF TWO PLATES SEPARATED BY AN ELASTIC CORE, LOADED BY A MOVING POINT FORCE}

In this example we consider vibrations of a system composed of two plates separated by an elastic core resting on deformable foundation and loaded with a moving force. The motion of plates in such arrangement is described by the following set of differential equations of motion:

$$
\begin{gathered}
D_{1} \nabla^{4} w_{1}(x, y, t)+m_{1} \frac{\partial^{2} w_{1}(x, y, t)}{\partial t^{2}}+k_{1}\left[w_{1}(x, y, t)-w_{2}(x, y, t)\right]=P \delta(x-v t) \delta\left(y-y_{0}\right), \\
D_{2} \nabla^{4} w_{2}(x, y, t)+m_{2} \frac{\partial^{2} w_{2}(x, y, t)}{\partial t^{2}}+k_{1}\left[w_{2}(x, y, t)-w_{1}(x, y, t)\right]+k_{2} w_{2}(x, y, t)=0,
\end{gathered}
$$

where:

$D_{1}$ and $D_{2}$ - flexural stiffness of the top and bottom plates respectively, $m_{1}$ and $m_{2}$ - unit masses of the top and bottom plates respectively, $k_{1}$ - elastic constant of the core layer, $k_{2}$ - elastic constant of the lower elastic foundation layer, $P$ - force moving on the top plate parallel to edge $x$ at a distance of $y_{0}$ from the edge. 
In this example we present a method of modelling elastic visco-elastic action using a combination method. The foundation is modelled, similarly to the example in 2 above, by using the default algorithm of the VDLOAD subroutine and the elastic core layer is represented by spring finite elements, as in Sec. 3 above.

Both plates are 5.0 by $7.0 \mathrm{~m}$ in size. Poisson's ratio of $v=0.167$ was adopted for both plates. The remaining input parameters are given below. Top plate: $\rho_{1}=2,500 \mathrm{~kg} / \mathrm{m}^{3}, E_{1}=38,600 \mathrm{MPa}$, $h_{1}=0.18 \mathrm{~m}$. Bottom plate: $\rho_{2}=2,000 \mathrm{~kg} / \mathrm{m}^{3}, E_{2}=23,100 \mathrm{MPa}, h_{2}=0.20 \mathrm{~m}$. Elastic constants of the elastic core layer and of the foundation: $k_{1}=1,100 \mathrm{MN} / \mathrm{m}^{3}, k_{2}=110 \mathrm{MN} / \mathrm{m}^{3}$. We assume that the vertical movements on the plate perimeter are prevented for both plates. The system is subjected to the action of a point force of $P=115 \mathrm{kN}$ moving at a constant speed of $v=30 \mathrm{~m} / \mathrm{sec}$. The path of the load is parallel to the longer side and coincides with the top slab axis of symmetry.

Each plate is made up of 140 finite elements of S4R type (see [1]). The elastic core layer is modelled by 117 spring type discrete finite elements. Fig. 6 shows an overview of the system with the deformed plates and elastic elements presented against the contour lines of twisting moments at a given point in time.

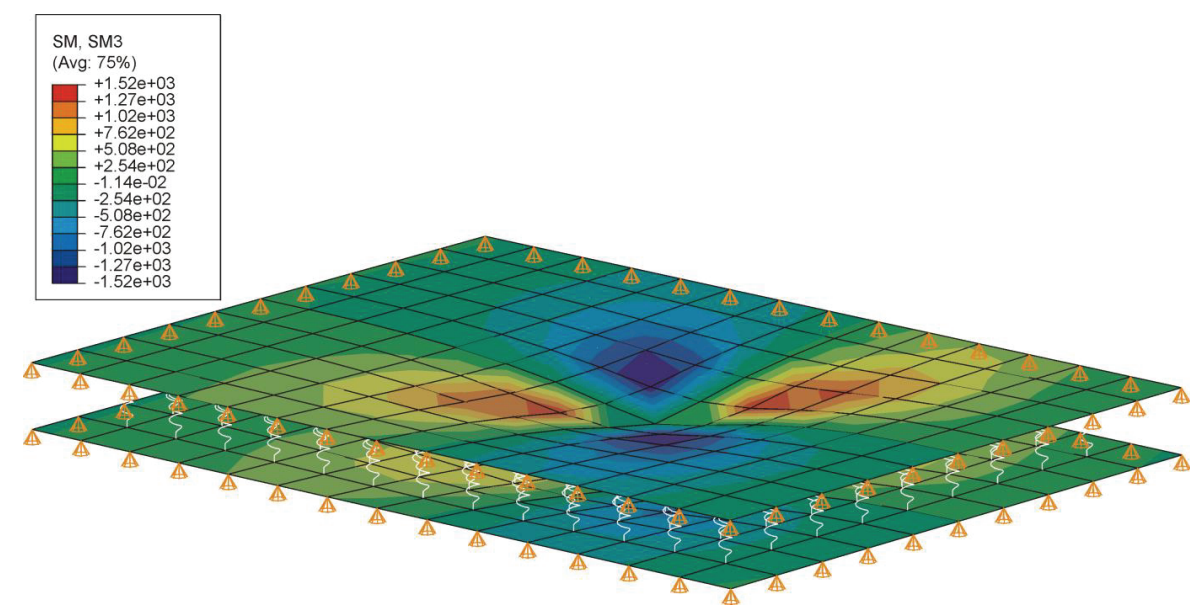

Fig. 6. Overview of the analysed deformed system against the twisting moment contour lines at the point in time of $\mathrm{t}=0.1363 \mathrm{sec}$. (vertical displacements are exaggerated 1000 times) 
The curves in Fig. 7 represent the vibrations of the centre points of both plates. One can clearly see considerable differences between the maximum deflections in the case of forced vibrations excited by the load moving on the structure. On the other hand, free vibrations of both plates (when the load has left the slab) have almost the same frequencies and amplitudes.

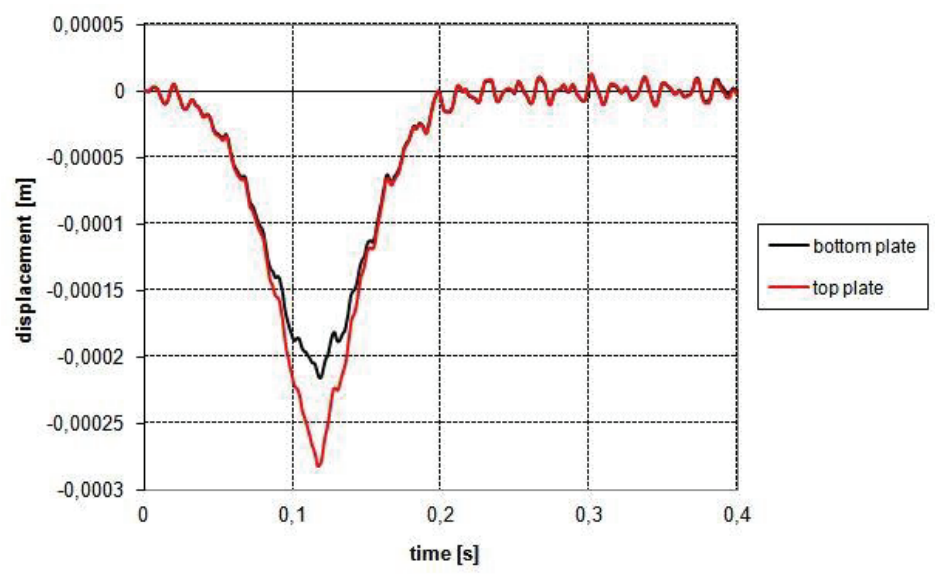

Fig. 7. Variation of centre point displacements over time for the top and bottom plates

In the above example with no damping both the core layer and the foundation are considered ideally elastic materials. Below are the results of a comparative analysis of the influence of the damping coefficient of the foundation on the behaviour of the entire system. Two input values were used in the analysis: $c=10 \mathrm{kNs} / \mathrm{m}^{3}$ and $c=1000 \mathrm{kNs} / \mathrm{m}^{3}$. 


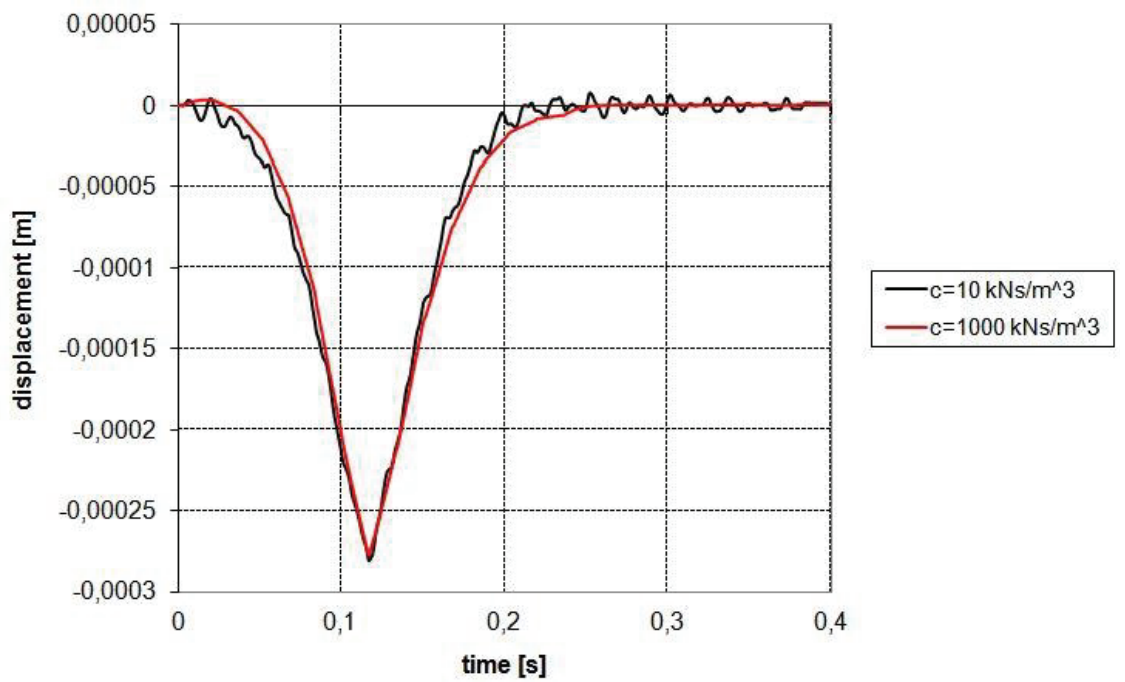

Fig. 8. Change over time of vertical displacements of the top slab centre point for different values of the damping coefficient of foundation

With clearly seen influence of damping there are only small differences between the maximum displacements at the analysed point of the plate.

\section{FinAL CONCLUSIONS}

In ABAQUUS the problems of vibrations induced in structures by a load of any type, changing over time and space are solved by direct integration of the state equations. These methods, also known as step-by-step integration are applied to the equations of motion without any transformations. It is assumed that the dynamic equilibrium equation must hold true only at specified points in time rather than over the continuous set of the time variable. Thus the problem-solving algorithm is reduced to finding solution at the new time step depending on the solutions at the previous time step.

If the traffic conditions at the time step $i$ are used to find solution at the new time step $i+1$ we are using an explicit scheme. In the implicit scheme the solution at the time step $i+1$ is obtained by satisfying the equation of motion at the same time step (Gomuliński and Witkowski [20]).

The group of explicit schemes includes the central difference and Runge-Kutta schemes. The other group of implicit schemes includes Newmark's method and Gear's method. Two of them, namely 
the Runge-Kutta and Gear's methods are not commonly used in the area of structural mechanics as they require converting the equations of motion to a set of differential equations of the $1^{\text {st }}$ order. This operation leads to obtaining a non-symmetrical state matrix.

Step-by-step integration involves much more algebraic operations. The number of operations increases with the increasing size of the matrix and with the increasing number of time steps. Hence, mode-superposition method is used in many situations. In this method the equations of motion are transformed using eigenvector matrix obtained from eigenproblem solution. The transformation by modal matrix yields a set of uncoupled differential equations which can be solved for any excitation by using the Duhamel's integral.

ABAQUS provides two "solver" modules: Explicit and Standard. In the Explicit solver the central difference method is used to integrate the equations of motion. The other analysis module Standard has an implemented solution procedure based on the mode-superposition method. Besides, for analysing so-called short-term processes the system employs the Hilber, Hughes and Taylor (HHT) operator (1978) based on the conventional Newmark's differential equations integration scheme extended by introduction of an additional damping parameter $\alpha \in\langle-1 / 3 ; 0\rangle$ (see [1]). The parameter of $\alpha$ enables eliminating the so-called numerical noise associated with high frequencies and occurring in problems solved with routines using variable integration step size. At $\alpha=0$ Newmark's scheme is obtained $(\beta=1 / 4)$ due to constant integration step size.

The next difference in the integration algorithms employed by ABAQUS is related to the form of the mass matrix. The Explicit scheme uses a diagonal matrix to uncouple the equations of motion. The Standard module uses the consistent mass matrix which employs the same shape functions which are found in the description of the displacement field (Zienkiewicz [75], [76]).

In the analytical examples provided in this paper we used Explicit module, yet it is possible to carry out conversion with the use of Implicit solver. The capabilities of the two solvers for analysing the dynamic behaviour of elastic-plastic systems are compared in the paper of Zbiciak [73]. 


\section{REFERENCES}

1. ABAQUS Analysis User's Manual, Ver. 6.9. Dassault Systèmes, 2009.

2. ABAQUS User Subroutines Reference Manual, Ver. 6.9, Dassault Systèmes, 2009.

3. J. Akin, M. Mofid, „Numerical Solution for Response of Beams with Moving Mass”, Journal of Structural Engineering, Vol. 115, No. 1, January 1989, pp. 120-131.

4. M. Ataman, „Analiza drgań belki warstwowej na podłożu Winklera obciążonej ruchomym oscylatorem”, Księga Konferencyjna 11-go Seminarium Polsko-Ukraińskiego, OWPW, Warszawa 2003, str. 261-268.

5. M. Ataman, W. Szcześniak, „Drgania płyty warstwowej na podłożu Winklera obciążonej ruchomym oscylatorem”, Księga Konferencyjna 12-go Seminarium Polsko-Ukraińskiego, OWPW, Warszawa 2004, str. 17-26.

6. M. Ataman, W. Szcześniak, „Vibrations of a non-homogenous Timoshenko beam on a two-parameter foundation subject to a moving load", Vibration Problems ICOVP 2011. The 10th International Conference on Vibration Problems, Proceedings, Prague 2011, pp.149-154.

7. M. Ataman, W. Szcześniak, „Dynamic Stability of an Infinite Non-Homogenous Euler's Beam Resting on a Three-Parameter Inertial Foundation, Subjected to a Moving Distributed Load", Science Direct, Elsevier 2014, Procedia Engineering, pp. 75-80.

8. C.I. Bajer, „Metoda elementów czasoprzestrzennych w obliczeniach dynamiki konstrukcji”, Biblioteka Mechaniki Stosowanej, IPPT PAN Warszawa, 2009, str.1-292.

9. C.I. Bajer, B. Dyniewicz, „Numerical analysis of vibrations of structures under moving inertial load”, Springer, 2012, pp.1-294.

10. A.G. Bartshenkov, „Dinamicheskijj raschet avtodorozhnykh mostov”, Izdatelstvo «TRANSPORT», Moskva 1976.

11. V.V. Bolotin, „O vozdejjstvii podvizhnojj nagruzki na mosty”, Trudy MIIT, vypusk 74, 1950, str. 269-296.

12. V.V. Bolotin, „O dinamicheskom raschete zheleznodorozhnykh mostov s uchetom massy podvizhnojj nagruzki”, Trudy MIIT, vypusk 76, 1952, str. 87-107.

13. V.V. Bolotin, „Zadacha o kolebanijakh mostov pod dejjstvii podvizhnojj nagruzki”, Izv. Akademii Nauk SSSR OTN, ,Mekhanika i mashinostroenie”, № 4, 1961, str. 109-115.

14. N.G. Bondar, I.I.Kazejj, B.F. Lesokhin, JU.G. Kozmin, „Dinamika zheleznodorozhnykh mostov”, Izdatelstvo «Transport», Moskva 1965.

15. D. Bryja, R. Hołubowski, „Wpływ dużych prędkości w analizie stochastycznych drgań mostu kolejowego z losowo zmienną sztywnością podsypki” Journal of Civil Engineering, Environment and Architecture JCEEA, t. XXX I, z. 61 (2/14), kwiecień-czerwiec 2014, str. 15-32.

16. A. Clebsch, „Theorie der Elastizität fester Körper” (francuskie tłumaczenie przez Barré de Saint-Venant), Paris 1883 .

17. A.P. Filippov, S.S. Kokhmanjuk, „Dinamecheskoe vozdejjstve podvizhnykh nagruzok na sterni”, Naukova Dumka, Kiev 1967.

18. L. Frýba, „Dynamics of railway Bridges”, Thomas Telford, London 1996.

19. L. Frýba, „Vibration of solids and structures under moving loads”, Thomas Telford, 1999.

20. . Gomuliński, M. Witkowski, „Mechanika budowli. Kurs dla zaawansowanych”, OWPW, Warszawa 1993.

21. J. Hino, T. Yoshimura, K. Konishi, N. Ananthanarayana, „A finite element method prediction of the vibration of a bridge subjected to a moving vehicle load" Journal of Sound and Vibration, Volume 96, Issue 1, 1984, pp. 45-53.

22. C.E. Inglis, „A mathematical treatise on vibrations in railway bridges”. Cambridge University Press, London 1934.

23. N.Z. Jakushev, „Dinamika deformiruemykh sistem pod vozdejjstviem dvizhushhikhsja nagruzok”, Obzornye stati, chast I. Issledovanija po teorii plastin i obolochek. Sbornik VIII, 1972, Izdatelstvo Kazanskovo universiteta, str. 3-42.

24. N.Z. Jakushev, „Dinamika deformiruemykh sistem pod vozdejjstviem dvizhushhikhsja nagruzok”. Obzornye stati, chast III. Issledovanija po teorii plastin i obolochek. Vypusk 18, 1985, Izdatelstvo Kazanskovo universiteta, str. 3-56.

25. N.Z. Jakushev, „Dinamika deformiruemykh sistem pod vozdejjstviem dvizhushhikhsja nagruzok”, chast III (prodolzhenie), Glava II. Dinamika poluprostranstv pod dejjstviem podvizhnykh nagruzok. Issledovanija po teorii plastin i obolochek, vypusk 19, 1985, str. 158-171.

26. N.Z. Jakushev, „Dinamika stroitelnykh sistem pod vozdejjstviem dvizhushhikhsja nagruzok”, Obzornye stati, chast II. Poluprostranstva, plastinki i obolochki pod dejjstviem podvizhnykh nagruzok. Issledovanija po teorii plastin i obolochek. Sbornik IX, 1972, Izdatelstvo Kazanskovo universiteta, str. 118-156.

27. G. Karami, P. Malekzadeh, „In-plane free vibration analysis of circular arches with varying cross-sections using differential quadrature method", Journal of Sound and Vibration, 274, 2004, pp. 777-799. 
28. Z. Kączkowski, „O drganiach belki mostowej pod wpływem przesuwających się obciążeń”, Zeszyty Naukowe Politechniki Śląskiej, Budownictwo, z. 20, Gliwice 1967.

29. Z. Kączkowski, „Vibration of a beam under a moving load”, Proceedings of Vibration Problems, Vol. 4, No. 4, Warsaw 1963, pp. 357-373.

30. A.D. Kerr, „Continuously supported beams and plates subjected to moving loads - a survey”, SM Archives, 6 (1981), pp. 401-449.

31. M. Klasztorny, „Dynamika mostów belkowych obciążonych pociągami szybkobieżnymi”, WNT, Warszawa 2005.

32. M. Klasztorny, „Drgania jednotorowych mostów kolejowych wywołane ruchem pociągów z dużymi prędkościami”, Prace Naukowe Instytutu Inżynierii Lądowej Politechniki Wrocławskiej, 36, Monografie 13, Wrocław 1987.

33. I.A. Kolesnik, „Kolebanija kombinirovanykh arochnykh sistem pod dejjstviem podvizhnykh nagruzok”, Vishha shkola, Kiev-Doneck 1977.

34. A. Kriloff, „Über die erzwungenen Schwingungen von gleichförmigen elastischen Stäben”, Mathematische Annalen, LXI, 1905, pp. 211-234.

35. A.N. Krylov, „O nekotorykh differencialnykh uravnenijakh matematicheskojj fiziki, imejushhikh primenenie v tekhnicheskikh voprosakh", Izvestija Morskojj Akademii, OPB, 1913, vypusk 2.

36. A.N. Krylov, „Vibracija sudov” 1907, 1936, Sobranie Trudov, tom X, Izdatelstvo Akademii Nauk SSSR, Moskva 1948.

37. J. Langer, „Analiza dynamiczna przęsła mostowego obciążonego ruchomym pojazdem”, Archiwum Inżynierii Lądowej, tom 20, 4, 1974, str. 591-599.

38. J. Langer, „Studium dynamiki przęsła mostowego obciążonego ruchomym pojazdem”, Archiwum Inżynierii Lądowej, tom 19, 2, 1973, str. 255-262.

39. J. Langer, „Wybrane problemy drgań konstrukcji pod obciążeniem ruchomym”, Dynamika w układach fizycznych - X Sympozjum, Poznań 1982, str.7-22.

40. J. Langer, M. Klasztorny, „Drgania belki spowodowane obciążeniem inercyjnym w ruchu niejednostajnym”, XIX Konferencja Naukowa KI PAN i KN PZITB - Krynica 1973, str. 107-115.

41. Y.-H. Lin, M.W. Trethewey, „Finite element analysis of elastic beams subjected to moving dynamic loads”, Journal of Sound and Vibration, Volume 136, Issue 2, 22 January 1990, pp. 323-342.

42. G.T. Michaltsos, A.N. Kounadis, „The effects of centripetal and Coriolis forces on the dynamic response of light bridges under moving loads", Journal of Vibration and Control, 7, 2001, pp. 315-326.

43. A.B. Morgaevskij, L.P. Karpov, G.F. Nikitin, „Ob issledovanii velichiny dinamicheskogo vozdejjstvija podvizhnojj nagruzki s uchetom vysshikh garmonik”, Issledovanija po Teorii Sooruzhenijj, vypusk 16, 1968, str. $15-24$

44. Z.P. Mourelatos, M.G. Parsons, „A finite element analysis of beams on elastic foundation including shear and axial effects", Computer and Structures, Vol. 27, No. 3, 1987, pp. 323-331.

45. V.M. Muchnikov, „Nekotorye metody rascheta uprugikh sistem na kolebanija pri podvizhnojj nagruzke”, GILSA, Moskva 1953.

46. G.B. Muravskijj, „O zadache Villisa-Stokehsa”, Stroitelnaja Mekhanika i Raschet Sooruzhenijj, vypusk 4, 1985, str. 55-56.

47. J. Naleszkiewicz, „Z dynamiki belki mostowej”, Archiwum Mechaniki Stosowanej, t. V, z. 4, Warszawa 1953, str. 517-544.

48. Z. Oniszczuk, „Free transverse vibrations of elastically connected simply supported double-beam complex system", Journal of Sound and Vibration (2000) 232(2), pp. 387-403.

49. G. Pan, H. Okada, S.N. Atluri, „Nonlinear transient dynamic analysis of soil-pavement interaction under moving load: a coupled BEM-FEM approach", Engineering Analysis with Boundary Elements, Volume 14, Issue 1, Elsevier 1994, pp. 99-112.

50. A.G. Panovko, „Istoricheskijj ocherk razvitija teorii dinamicheskogo dejjstvija podvizhnojj nagruzki (k stoletiju postanovki problemy)", Trudy Leningradskojj Krasnoznamennojj Voenno-Vozdushnojj Inzhenernojj Akademii, Vypusk 17, Izdatelstvo LKVVIA, str. 8-38.

51. M. Radeş, „Dynamic analysis of an inertial foundation model”, Int. J. Solids Structures, 1972, Vol. 8, pp.13531372.

52. M. Renaudot, „Étude de l'influence des charges en mouvement sur la résistance, des ponts métallique a poutres droits", Annales des Ponts et Chausses, V. 1, 1861, p. 145-204.

53. M.N. Rutshimsky, „K voprosu o raschete balki nakhodjashhejjsja pod dejjstviem dvizhushhejjsja sily peremennojj velichiny”, Inzhenernyjj Sbornik, tom XI, 1952, str. 187-188.

54. G.G. Stokes, „Discussion of a differential equation relating to the breaking railway bridges”, Transactions of Cambridge Philosophical Society 1849, Part 5, pp. 707-735. Reprinted in Mathematical and Physical Papers, Cambridge, Vol. II, 1883, pp. 179-220. 
55. W. Szcześniak, „Drgania belki sandwiczowej pod wpływem ruchomego obciążenia bezinercyjnego”, Prace Naukowe Politechniki Warszawskiej, Budownictwo, z. 132, Warszawa 1998, str. 111-152.

56. W. Szcześniak, „Drgania płyty sandwiczowej pod wpływem ruchomego obciążenia bezinercyjnego”, Prace Naukowe Politechniki Warszawskiej, Budownictwo, z. 132, Warszawa 1998, str. 153-172.

57. W. Szcześniak, „Inercyjne obciążenia ruchome na belkach i płytach”, Prace Naukowe Politechniki Warszawskiej, Budownictwo, z. 112, OW PW, Warszawa 1990.

58. W. Szcześniak, „Problemy ruchomych obciążeń w Polsce. Przegląd podstawowych pozycji literatury”, Theoretical Foundations of Civil Engineering. Polish-Ukrainian Transactions, OW PW, Warszawa 1993, pp. 191-198.

59. W. Szcześniak, „Wybrane zagadnienia belek i powłok poddanych inercyjnym obciążeniom ruchomym”. Prace Naukowe Politechniki Warszawskiej, Budownictwo, z. 125, OWPW, Warszawa 1994.

60. W. Szcześniak, M. Ataman, A. Zbiciak, „Drgania belki sprężystej wywołane ruchomym, liniowym oscylatorem jednomasowym”, Drogi i Mosty, nr 2/2002, Instytut Badawczy Dróg i Mostów, Warszawa 2002, str. 53-84.

61. W. Szcześniak, M. Ataman, „Pewien sposób znajdowania zamkniętej postaci drgań czysto wymuszonych w zadaniu Kryłowa", Theoretical Foundations of Civil Engineering. Polish-Ukrainian Transactions, OW PW, Warszawa 2001, pp. 413-432.

62. W. Szcześniak, M. Ataman, A. Zbiciak, „Pasywne tłumienie mechaniczne drgań belki mostowej obciążonej ruchomym oscylatorem trój masowym”, Prace Naukowe Politechniki Radomskiej, Transport nr 1(15), Radom 2002, str. 505-512.

63. W. Szcześniak, M. Ataman, A. Zbiciak, „Zastosowanie programu Simulink do analizy drgań układu mechanicznego pojazd-belka z uwzględnieniem nierówności toru”, Prace Naukowe Politechniki Radomskiej, Transport nr 1(15), Radom 2002, str. 527-534.

64. W. Szcześniak, A. Zbiciak, M. Ataman, „Analiza drgań poprzecznych prostokątnej płyty sprężystej zamocowanej na całym obwodzie pod ruchomym oscylatorem lepko sprężystym”, Księga Konferencyjna 10go Seminarium Polsko-Ukraińskiego, OWPW, Warszawa 2002, str. 399-420.

65. P. Śniady, „Drgania belki wywołane losowym strumieniem ruchomych mas skupionych”, Zeszyty Naukowe Politechniki Świętokrzyskiej, Budownictwo 18, Materiały Konferencji „Obciążenia ruchome w dynamice konstrukcji”, Kielce 1984, str. 119-124.

66. P. Śniady, „Drgania dźwigarów wywołane ruchomym obciążeniem”, Prace Naukowe Instytutu Inżynierii Lądowej Politechniki Wrocławskiej, 21, Monografie 5, Wrocław 1976.

67. P. Śniady, „Podstawy stochastycznej dynamiki konstrukcji” OW PWr, Wrocław 2000.

68. P. Śniady, „Zamknięte postacie aperiodycznych drgań dźwigarów półnieskończonych”, Archiwum Inżynierii Lądowej, tom XX, z. 4, 1974, str. 601-608.

69. E.C. Ting, J. Genin, J.H. Ginsberg, „Dynamic interaction of bridge structures and vehicles”, The Shock and Vibration Digest, Vol. 7, No 11, 1975, pp. 61-69.

70. F. Venancio-Filho, „Finite element analysis of structures under moving loads”, The Shock and Vibration Digest, Vol. 10, No 8, August 1978, pp. 27-35.

71. D.B. Volper, A.B. Morgaevskij, „O dinamicheskom vozdejjstvii podvizhnojj nagruzki pri bolshikh skorostjakh dvizhenija”, Issledovanija po Teorii Sooruzhenijj, Vypusk 12, 1963, str. 21-42.

72. Y.B. Yang, J.D. Yau, Y.S. Wu, „Vehicle-bridge interaction dynamics with applications to high-speed railway”, World Scientific, Singapore 2004.

73. A. Zbiciak, „Analiza porównawcza rozwiązań płaskich zagadnień początkowo-brzegowych teorii sprężystoplastyczności w systemach MATLAB i ABAQUS”, XIV Konferencja Polsko-Ukraińsko-Litewska "Theoretical Foundations of Civil Engineering", str. 449-458, OWPW, Warszawa 2006.

74. A. Zbiciak, R. Oleszek, R. Michalczyk, „Dynamics of an orthotropic railway bridge in the light of European standards", Archives of Civil Engineering, Vol. LXII, ISSUE 2, 2016, pp.265-262.

75. O.C. Zienkiewicz, „Metoda elementów skończonych”, Arkady, Warszawa 1972.

76. O.C. Zienkiewicz, R.L. Taylor, "The Finite Element Method”, Fifth edition. Butterworth-Heinemann, Oxford 2000.

77. H. Zimmermann, „Die Schwingungen eines Trägers mit bewegter Last”, Centralblatt der Bauverwaltung 16, 1896, No. 23, 249-251, No. 23A, 257-260, No. 24, 264-266, No. 26. 


\section{LIST OF FIGURES AND TABLES:}

Fig. 1. Comparative analysis of midpoint deflections determined with the finite-element method and analytically with the load moving at a speed of $v=20 \mathrm{~m} / \mathrm{sec}$.

Rys. 1. Analiza porównawcza rozwiązania zadania MES i metodą analityczną

Fig. 2. Midpoint vibration curves for different load distribution lengths

Rys. 2. Wykresy drgań punktu w środku rozpiętości belki przy różnych wartościach długości odcinka obciążenia

Fig. 3. Overview of the analysed system against the equivalent stress contour lines (outer fibres of beams) at the point in time of $t=0.1425 \mathrm{sec}$. (vertical displacements are exaggerated 6 times)

Rys. 3. Widok układu na tle warstwic naprężeń zastępczych (skrajne włókna belek), w chwili $t=0,1425 \mathrm{~s}$ (przemieszczenia pionowe powiększono 6-krotnie)

Fig. 4. Change of midpoint displacements over time for the top and bottom beams

Rys. 4. Przebieg w czasie przemieszczeń pionowych punktów środkowych belki dolnej i górnej

Fig. 5. Influence of boundary conditions on the curve describing midpoint vertical displacements of the top beam for different end support conditions

Rys. 5. Wpływ warunków brzegowych na przebieg w czasie przemieszczeń pionowych środka belki górnej, przy różnych warunkach podparcia na końcach belek

Fig. 6. Overview of the analysed deformed system against the twisting moment contour lines at the point in time of $\mathrm{t}=0.1363 \mathrm{sec}$. (vertical displacements are exaggerated 1000 times)

Rys. 6. Widok odkształconego układu na tle warstwic momentów skręcających, w chwili $t=0,1336 \mathrm{~s}$

(przemieszczenia pionowe powiększono 1000-krotnie)

Fig. 7. Variation of centre point displacements over time for the top and bottom plates

Rys. 7. Przebieg w czasie przemieszczeń pionowych punktów środkowych płyty dolnej i górnej

Fig. 8. Change over time of vertical displacements of the top slab centre point for different values of the damping coefficient of foundation

Rys. 8. Przebieg w czasie przemieszczeń pionowych środka płyty górnej, przy różnych wartościach współczynnika thumienia w podłożu 


\title{
Zastosowanie Mes do Wyznaczania Drgań Belek i Plyt na Podlożach Odksztalcalnych POD OBCIĄŻENIEM RUCHOMYM
}

\author{
Słowa kluczowe: drgania belek i płyt niejednorodnych poprzecznie, podłoża odkształcalne, obciążenia ruchome skupione i \\ rozłożone, MES
}

\section{STRESZCZENIE}

Ograniczeniem zastosowania metod analitycznych do rozwiązania zagadnień dynamicznych belek i płyt pod obciążeniami ruchomymi są przede wszystkim trudności w spełnieniu warunków brzegowych w belkach i płytach. Z tego też powodu w większości przypadków stosuje się metody przybliżone typu MES, MECZ, MEB, DQM oraz metodę różnic skończonych, w których łatwo jest zamodelować dowolne warunki brzegowe. Metody te pozwalają również na uwzględnienie różnorodności materiałów i elementów konstrukcyjnych.

W niniejszej pracy przedstawiono możliwości wykorzystania programu metody elementów skończonych (MES) ABAQUS [1] do modelowania belek i płyt warstwowych spoczywających na odkształcalnych podłożach. Układy takie poddano działaniu ruchomych obciążeń, zarówno skupionych jak i rozłożonych. W kilku przykładach pokazano różne techniki modelowania podłoża i ruchomego obciążenia.

Należy wyraźnie zaznaczyć, że przedstawione tutaj procedury wykraczają poza klasyczne wykorzystanie programu ABAQUS. Opisu omówionych technik nie znajdziemy w podręcznikach użytkownika wymienionego programu. Częstokroć też korzystano $\mathrm{z}$ narzędzi, których standardowe wykorzystanie dotyczy zupełnie innego obszaru zastosowań. Przykładem tego jest np. modelowanie podłoży lepko-sprężystych za pośrednictwem procedury użytkownika VDLOAD ([2]). Z dokumentacji ABAQUS-a [1] można dowiedzieć się, że programowanie algorytmów w ramach tej procedury, pozwala jedynie na zadawanie zmiennych w czasie obciążeń. Podobną trudność napotyka się chcąc zadać ruchome obciążenie bezinercyjne - skupione albo rozłożone. Informacji na ten temat również próżno szukać w cytowanej dokumentacji.

Program ABAQUS, podobnie jak systemy ANSYS i LS-DYNA, charakteryzuje się otwartą strukturą, która pozwala na dołączanie tzw. procedur użytkownika (np. wspomniana wyżej procedura VDLOAD). Za ich pomocą możliwe jest zaprogramowanie własnych modeli materiałów, warunków brzegowych oraz zdefiniowanie nowych elementów skończonych. Procedury użytkownika mogą być również wykorzystane do zadawania nietypowych obciążeń a także są przydatne na etapie obróbki uzyskanych wyników. Wraz z każdą nową wersją pojawiają się kolejne procedury, dzięki którym system oferuje większe możliwości obliczeniowe. Algorytm danego zagadnienia należy zaprogramować w języku FORTRAN i dołączyć kod źródłowy na etapie przedkładania zadania do analizy. Proces kompilacji i linkowania jest wykonywany przez system pod warunkiem, że w maszynie obliczeniowej zainstalowana jest odpowiednia wersja kompilatora, kompatybilna $\mathrm{z}$ daną wersją programu MES.

W systemie ABAQUS zagadnienia drgań konstrukcji, wywołane działaniem dowolnego, zmiennego w czasie i przestrzeni, obciążenia rozwiązywane są z wykorzystaniem metod bezpośredniego całkowania równań stanu. Metody te, zwane również metodami całkowania „krok po kroku”, stosuje się do równań ruchu nie poddanych żadnym transformacjom. Zakłada się przy tym, że równanie równowagi dynamicznej ma być spełnione tylko w wybranych chwilach, nie zaś w ciągłym zbiorze zmiennej czasowej. Algorytm rozwiązania sprowadza się do poszukiwania rozwiązań w chwili następnej, zależnie od rozwiązań w chwilach poprzednich. 
Jeżeli na podstawie warunków ruchu ułożonych $\mathrm{w}$ chwili $i$, wyznaczamy rozwiązanie $\mathrm{w}$ chwili $i+1$, to mamy do czynienia z tzw. schematem jawnym (ang. explicit). W przypadku algorytmów niejawnych (ang. implicit), rozwiązanie w chwili $i+1$ uzyskujemy spełniając równania ruchu w tej samej chwili (Gomuliński i Witkowski [20]).

Do grupy metod jawnych zalicza się np. metodę różnic centralnych i metodę Rungego-Kutty. Wśród metod niejawnych wymienić można algorytmy Newmarka oraz Geara. Metody Rungego-Kutty i Geara nie znalazły szerszego zastosowania w mechanice konstrukcji, gdyż wymagają one sprowadzenia równań ruchu do układu równań różniczkowych I-go rzędu. Operacja ta prowadzi do niesymetrycznych macierzy stanu.

Całkowanie metodą „krok po kroku” wymaga wykonania znacznej liczby działań algebraicznych. Liczba ta jest tym większa, im większe są wymiary macierzy i większa liczba kroków czasowych. Dlatego też, w wielu przypadkach stosuje się tzw. metodę superpozycji modalnej. Polega ona na przetransformowaniu równań ruchu z wykorzystaniem macierzy wektorów własnych uzyskanej z rozwiązania zagadnienia własnego. Transformacja modalna (własna) pozwala na uzyskanie układu niezależnych równań różniczkowych, które można rozwiązać przy dowolnym wymuszeniu, korzystając z tzw. całki Duhamela.

W systemie ABAQUS dostępne są dwa moduły obliczeniowe: Explicit i Standard. W module Explicit, równania ruchu całkowane są przy użyciu metody różnic centralnych. Moduł Standard ma zaimplementowaną procedurę rozwiązywania zagadnień metodą superpozycji modalnej. Oprócz tego, do analizy tzw. procesów przejściowych, system wykorzystuje niejawny algorytm zaproponowany przez Hilbera, Hughesa i Taylora (1978), który oparty jest na klasycznym schemacie różnicowym Newmarka, gdzie wprowadzono dodatkowy parametr tłumienia $\alpha \in\langle-1 / 3 ; 0\rangle$ (patrz [1]). Parametr $\alpha$ umożliwia eliminowanie tzw. szumu numerycznego, związanego z wysokimi częstościami, który pojawia się w zagadnieniach rozwiązywanych przy użyciu algorytmów ze zmiennym krokiem całkowania. Przyjęcie $\alpha=0$, prowadzi do schematu Newmarka $(\beta=1 / 4)$, ze względu na stały krok całkowania.

Kolejna różnica występująca w algorytmach całkowania w programie ABAQUS, związana jest z postacią macierzy mas elementu. W module Explicit ma ona formę diagonalną, dzięki czemu możliwe jest rozprzęgnięcie równań ruchu. Moduł Standard wykorzystuje tzw. konsystentną (albo konsekwentną) formę macierzy mas tzn. taką, w której stosuje się te same funkcje kształtu, które występują w opisie pola przemieszczeń (Zienkiewicz [75], [76]).

Przykłady obliczeniowe opisane w pracy zostały wykonane w module Explicit, choć jest możliwe ich przeliczenie z wykorzystaniem solvera Implicit. Analizę porównawczą możliwości obydwu modułów, w kontekście dynamiki układów sprężysto-plastycznych, zawiera praca Zbiciaka [73]. 